\title{
A Newly-developed High Wear Resistant Cast Hot-forging Die Steel
}

\author{
Shugi WANG, Feng WANG, K. M. CHEN and Xianghong CUI \\ School of Materials Science and Engineering, Jiangsu University, No. 301 Xuefu Road, Zhenjiang 212013, Jiangsu, China. \\ E-mail: shuqi_wang@ujs.edu.cn
}

(Received on November 10, 2006; accepted on June 13, 2007)

\begin{abstract}
The alloying design of the cast hot-forging die steels was analyzed. The key property and parameters for the alloying design were selected. The cast hot-forging die steel with high wear resistance was developed through optimizing the parameters. The wear resistance of the newly-developed cast die steel was evaluated in comparison with commercial H13 steels and 3Cr2W8V steel. The wear mechanism is also discussed. The newly-developed cast die steel takes VC as predominant carbide with solid solution strengthening of $\mathrm{Cr}$ and Mo. The cast die steel was found to have significantly lower wear rate than normal H13 steel and $3 \mathrm{Cr} 2 \mathrm{~W} 8 \mathrm{~V}$ steel, and almost the same wear rate as high-purified $\mathrm{H} 13$ steel. The high wear resistance of the new-developed cast die steel could be attributed to the reasonable alloying design and no sensitivity to detrimental function of $S$ and $P$. Under the elevated-temperature air at $400^{\circ} \mathrm{C}$, the wear for the cast die steels and commercial hot-forging die steels is a typical oxidation wear.
\end{abstract}

KEY WORDS: hot-forging die; cast steel; wear resistance; oxidation wear.

\section{Introduction}

Cast dies as a new alternative for hot-forging dies have many advantages: high utilization ratio of materials, low finish allowance, short process time and regenerative use of obsolete dies. Cast hot-forging dies have been studied and applied since 1940's. Now cast hot-forging dies are manufactured and utilized in some countries. ${ }^{1-5)}$ It was found that the predominant failure pattern of hot-forging dies with high lives is elevated-temperature wear. ${ }^{6}$ And lives of cast hot-forging dies are needed to improve further, because their shorter lives are resulted from lower wear resistance. ${ }^{7)}$

Alloying design of the cast steels is key factor for cast hot-forging dies with long lives. The researches about alloying design of the cast hot-forging die steels are sparsely reported. The early-used cast die steels take the same composition as the commercial die steels, for instance, $5 \mathrm{CrN}$ iMo, $\left.5 \mathrm{CrMnMo}, \mathrm{H} 13 .{ }^{8}\right)$ Later the compositions of the cast hot-forging die steels are slightly adjusted on the basis of the commercial die steels, through addition of some alloying elements. The modified H13 cast steel is developed through addition of REM or $\mathrm{Ni}$, in order to improves some properties. $^{9,10)}$ It must be noted that these cast die steels usually have unreasonable alloying design, which causes no ideal properties. It is apparent that the alloying designs for as-forged steel are not suitable for as-cast steel. This is because as-cast steels have different characteristics from asforged steels. Alloying design for cast die steels should take advantage of superior properties of the cast steels, such as high thermal stability, high resistances to thermal fatigue and thermal wear, but avoid low plasticity.

The purpose of the research is to developed the cast hot- forging die steels with high wear resistance. Through analysis of alloying design, the parameters for alloying design of the cast hot-forging die steels were selected and optimized. The high wear resistant cast steels were developed through consulting optimized parameters. The microstructures of the newly-developed steel were examined. The elevatedtemperature wear resistance for the newly-developed cast hot-forging die steel was evaluated, in comparison with $\mathrm{H} 13$ steels and $3 \mathrm{Cr} 2 \mathrm{~W} 8 \mathrm{~V}$ steel. This research will provide basis data consulted for alloying design and utilization of cast hot-forging dies.

\section{Experimental Procedure}

The compositions of the new-developed cast die steel and commercial die steels are exhibited in Table 1 . The cast steel was melted in $250 \mathrm{~kg}$ medium frequency induction furnace with non-oxidation method. As reaching $1550^{\circ} \mathrm{C}$, the melt was deoxidized with $\mathrm{Al}$, and then poured. The modified agents containing REM were put in ladle for modification of the melt. Finally the standard hedge samples were cast. The cast steel was austenitized at $1020^{\circ} \mathrm{C}$ for $1 \mathrm{~h}$ and quenched in oil, then tempered at $440^{\circ} \mathrm{C}$ or $600^{\circ} \mathrm{C}$ for $2 \mathrm{~h}$.

The commercial H13 steels and 3Cr2W8V steel were selected as the contrasting steels for evaluating wear resistance of the cast die steel. Two kinds of commercial H13 steels are respectively high-purified H13 steel with low content of S and P (signified as H13-1) and normal H13 steel (signified as H13-2). The commercial H13 steels were austenitized at $1040^{\circ} \mathrm{C}$ for $1 \mathrm{~h}$ and cooled in oil, and then tempered at $600^{\circ} \mathrm{C}$ or $620^{\circ} \mathrm{C}$ for $2 \mathrm{~h}$. The commercial 
Table 1. Compositions of the new-developed cast steel and commercial steels.

\begin{tabular}{|c|c|c|c|c|c|c|c|c|}
\hline \multirow{2}{*}{ Steels } & \multicolumn{8}{|c|}{ Compositions, wt.\% } \\
\hline & $\mathrm{C}$ & $\mathrm{Si}$ & $\mathrm{Mn}$ & S & $P$ & $\mathrm{Cr}$ & $\operatorname{Mo}\left(W^{*}\right)$ & V \\
\hline The cast steel & 0.3765 & 0.5862 & 0.4568 & 0.0133 & 0.0183 & 3.6712 & 2.5694 & 1.1757 \\
\hline $\mathrm{H} 13-1$ & 0.3990 & 1.0336 & 0.3237 & 0.0015 & 0.0093 & 4.9157 & 1.6557 & 0.8377 \\
\hline H13-2 & 0.4160 & 0.9403 & 0.2698 & 0.0018 & 0.0184 & 5.3368 & 1.4091 & 0.8284 \\
\hline $3 \mathrm{Cr} 2 \mathrm{~W} 8 \mathrm{~V}$ & 0.3622 & 0.2649 & 0.2863 & 0.0146 & 0.0264 & 2.5236 & $8.1857 *$ & 0.3246 \\
\hline
\end{tabular}

$3 \mathrm{Cr} 2 \mathrm{~W} 8 \mathrm{~V}$ steel was austenitized $1060^{\circ} \mathrm{C}$ for $1 \mathrm{~h}$ and cooled in oil, finally tempered at $620^{\circ} \mathrm{C}$ or $660^{\circ} \mathrm{C}$ for $2 \mathrm{~h}$.

The wear tests were performed on a uni-directional pinon-disk high-temperature wear tester (MG-2000 type, made by Xuan Hua material testing machine factory of China). The wear test rig used in this study has been described in detail elsewhere. ${ }^{11)}$ All wear tests were carried out at $400^{\circ} \mathrm{C}$ without lubrication. The test parameters were selected as follows: $100 \mathrm{~N}$ for norm load; $1 \mathrm{~ms}^{-1}$ for sliding speed and $1.8 \times 10^{3} \mathrm{~m}$ for sliding distance. Pins with dimensions of $\Phi 6 \mathrm{~mm} \times 12 \mathrm{~mm}$ are made of the studied cast steels and commercial die steels. The disks with dimensions of $\Phi 70 \mathrm{~mm} \times 8 \mathrm{~mm}$ are made of D2 steel with 58HRC.

Before test, pins and disks were polished and degreased. The pin specimens were cleaned with acetone and dried before and after test for weighting wear loss by a balance with an accuracy of $0.01 \mathrm{mg}$. The wear rates were calculated in term of the formula: $W s=\Delta V / P \cdot d$, Where $\Delta V$ is wear volume loss $\left(\mathrm{m}^{3}\right)$, i.e. wear weight loss divided by density; $d$ is sliding distance $(\mathrm{m}), P$ is load $(\mathrm{N})$. All the data were average values for three or five wear experimental results.

The morphology, composition and structure of worn surface or wear debris were analyzed with an AMRA-1000B type scanning electron microscope (SEM) coupled with an energy-dipersive X-ray spectroscope (EDS) and a D/Max2500/pc type X-ray diffractometer (XRD). Thin foil samples for the cast steel were prepared for observing the microstructures using a Hitachi H-800 transmission electron microscope. The hardness and strength were measured with a HRC150 type durometer and a 1196 type multipurpose tester respectively.

\section{Alloying Design for Cast Hot-forging Die Steels}

\subsection{Analysis of Alloying Design}

Generally the high toughness was thought to be needed to forbid brittle fracture for application of the cast hot-forging die steels. Thus the improved toughness of the steels was always the basis of the alloying design for the cast hotforging die steels, and impact toughness was simply selected as toughness index. ${ }^{12)}$ It was true in most of prior researches that impact toughness was taken as basis of alloying design or as prerequisite. ${ }^{8)}$ Additionally in industry, impact toughness is also taken as important toughness index for selection of materials and process optimization or quality control. It was reported that impact toughness is specified to be not less than $30 \mathrm{~J} / \mathrm{cm}^{2}$ and $20 \mathrm{~J} / \mathrm{cm}^{2}$ respectively for forged steels and the cast steels in hot-forging die. ${ }^{13)}$ However, it is not fully clear for the relations of failure patterns and life of hot-forging dies with toughness requirement and toughness index.

Through failure analysis and property evaluation of cast hot-forging dies in our prior work, it was found that brittle fracture with shorter life sparsely happened except for the special cases in application of cast hot-forging dies and has nothing to do with impact toughness. ${ }^{12)}$ The results also proved that most of cast die steels satisfy for toughness requirement under the operating mode of hot-forging dies. The failure pattern and life is not related with impact toughness. So impact toughness as toughness index used in alloying design is not suitable for cast hot-forging dies.

Hot-forging dies are subject to multi-impact load, repeatedly cooling and heating and elevated-temperature friction with processed materials. The predominant failure patterns of cast hot-forging dies are brittle fracture (fatigue), elevated-temperature wear, plastic deformation and thermal fatigue. ${ }^{7,14-17)}$ As a result, the cast hot-forging die steels are needed to have high fatigue resistance, thermal strength, thermal fatigue resistance and wear resistance.

The multi-impact fatigue resistance, not impact toughness should be required to forbid brittle fracture. ${ }^{12)}$ If impact toughness is taken as key property for alloying design or selecting materials and process optimization, the properties related closely to life should be weakened; thus the lower life of dies is caused. For example, high impact toughness probably companies with lower thermal strength and wear resistance.

In spite of lower impact toughness, the cast steel was reported to have normally higher fatigue crack propagation resistance, thermal fatigue resistance, thermal stability and wear resistance than as-forged steel with the same composition. ${ }^{9)}$ Alloying design of the cast steel must take advantage of its merits and avoid its shortcoming. It is clear that current life of cast hot-forging die need to be improved further, because of low wear resistance resulted from unreasonable alloying design. Thus it is necessary and reasonable that elevated-temperature wear resistance is taken as key property for alloying design of cast hot-forging die steels.

\subsection{Parameters for Alloying Design and Its Optimiza- tion}

In the cast hot-forging die steels, $\mathrm{C}, \mathrm{Cr}$, Mo and $\mathrm{V}$ are predominant alloy elements. In order to guarantee certain amount of stable carbides and alloy element solution in $\alpha^{\prime}$ 
(Martensite), alloying design needs to attain reasonable distribution of alloy elements in carbides and $\alpha^{\prime}$. Stable carbides precipitated in $\alpha^{\prime}$ are considered to an effective way to increase wear resistance. However, alloy solution in $\alpha^{\prime}$ can ensure thermal strength and thermal stability, which is prerequisite for high wear resistance.

$\mathrm{VC}$ is relatively stable carbide. Only when tempering temperature reaches $700^{\circ}$, VC starts to coarsen. So VC is the most competitive carbide. A great amount of $\mathrm{VC}$ is needed to precipitate in the steel to elevate wear resistance. $\mathrm{Cr}$ and Mo had better be solubilized in $\alpha^{\prime}$, due to the fact that carbides of $\mathrm{Cr}$ and $\mathrm{Mo}$ are not as stable as $\mathrm{VC}$. $\mathrm{Cr}$ and Mo solubilized in $\alpha^{\prime}$ are helpful to improve thermal strength. In addition, it is well known that carbon is the strongest solution strengthening element. Thus some amount of carbon solubilized in $\alpha^{\prime}$ is also needed.

It has been found in our prior work ${ }^{11)}$ that wear rate is mainly dependant on the type of carbide. Additionally wear rate is also related with other factors, such as solutions of $\mathrm{Cr}$ and $\mathrm{Mo}$ in $\alpha^{\prime} . \mathrm{V} / \mathrm{C}$ (weight ratio of $\mathrm{V}$ to $\mathrm{C}$ ), $\mathrm{C}_{\text {residual }}$ (residual carbon weight percent after $\mathrm{VC}$ is formed) and $\mathrm{Cr} /(\mathrm{Cr}+\mathrm{Mo})$ (molar ratio of $\mathrm{Cr}$ to $\mathrm{Cr}+\mathrm{Mo})$ is considered to be important parameters, which decide type and amount of predominant carbide. ${ }^{11)}$ The alloying design parameters for the cast hot-forging die steels were optimized as follows.

As $\mathrm{V} / \mathrm{C}$ ranges in $3-3.6,{ }^{18)}$ enough $\mathrm{VC}$ as predominant carbide is precipitated in $\alpha^{\prime}$. On the above basis, $\mathrm{C}_{\text {residual }}$ is reduced as far as possible. In this case, the amount of carbides of $\mathrm{Cr}$ and Mo is decreased, thus solution of $\mathrm{Cr}$ and Mo in $\alpha^{\prime}$ can be ensured. Meanwhile, high wear resistance is ensured as $\mathrm{C}_{\text {residual }}$ is equal to $0.07-0.15 .{ }^{11)}$

As $\mathrm{VC}$ is not as predominant carbide, the types of carbides of $\mathrm{Cr}$ or Mo needs to be controlled through variation of $\mathrm{Cr} / \mathrm{Cr}+\mathrm{Mo}$. As $\mathrm{Cr} / \mathrm{Cr}+\mathrm{Mo}$ ranges $0.65-0.73, \mathrm{Cr}_{7} \mathrm{C}_{3}$ and $\mathrm{Mo}_{2} \mathrm{C}$ coexist in the cast hot-forging die steel. In this case, the wear resistance was proved to be better. ${ }^{18)}$ However, excess amount of Cr-dominated carbide or Mo-dominant carbide precipitates as $\mathrm{Cr} / \mathrm{Cr}+\mathrm{Mo}$ is more than 0.73 , or less than 0.65 . Much precipitation of $\mathrm{Cr}$-dominant carbide reduce thermal strength resulted from reduction of $\mathrm{Cr}$ in $\alpha^{\prime}$. As $\mathrm{Cr} / \mathrm{Cr}+\mathrm{Mo}$ is less than $0.65, \mathrm{Mo}_{6} \mathrm{C}$ precipitates along boundary of grain and lathes. ${ }^{19)}$ The two cases both deteriorate wear resistance. Especially, the latter must be restrained.

\section{Microstructure and Wear Resistance of the New- developed Cast Die Steel}

\subsection{Microstructure}

The optimized cast steel was developed in terms of the above alloying design parameters, whose composition is shown in Table 1 . The steel was austenitized at $1020^{\circ} \mathrm{C}$ for $1 \mathrm{~h}$, quenched in oil to attain complex microstructure including martensite and bainite. ${ }^{11)}$

After tempered at $440^{\circ} \mathrm{C}$ or $600^{\circ} \mathrm{C}$, the pin specimens with the tempered microstructures were used for wear test. Figure 1 shows the tempered microstructures of the optimized cast steel. When tempered at $200-300^{\circ} \mathrm{C}, \mathrm{Fe}_{3} \mathrm{C}$ precipitates in $\alpha^{\prime}$ through decomposition of supersaturated solution $\left(\alpha^{\prime}\right)$. When tempering at $440^{\circ} \mathrm{C}$, chromium in $\alpha^{\prime}$ diffuses into $\mathrm{Fe}_{3} \mathrm{C}$ to form (Fe, $\left.\mathrm{Cr}\right)_{3} \mathrm{C}$, as shown in Figs. 1(a), 1(b). It was reported that $(\mathrm{Fe}, \mathrm{Cr})_{7} \mathrm{C}_{3}$ and $\mathrm{Mo}_{2} \mathrm{C}$ start to precipitate at $500^{\circ} \mathrm{C}$, and $\mathrm{VC}$ precipitate at $550{ }^{\circ} \mathrm{C}$. ${ }^{20)}$ So after tempering at $500^{\circ} \mathrm{C}$, a bit of $(\mathrm{Fe}, \mathrm{Cr})_{7} \mathrm{C}_{3}$ and $\mathrm{Mo}_{2} \mathrm{C}$ are found to precipitate in $\alpha$. When tempering at $600^{\circ} \mathrm{C},(\mathrm{Fe}, \mathrm{Cr})_{7} \mathrm{C}_{3}$ and $\mathrm{Mo}_{2} \mathrm{C}$ start to grow (Figs. 1(e), 1(f), 1(g)), and fine VC

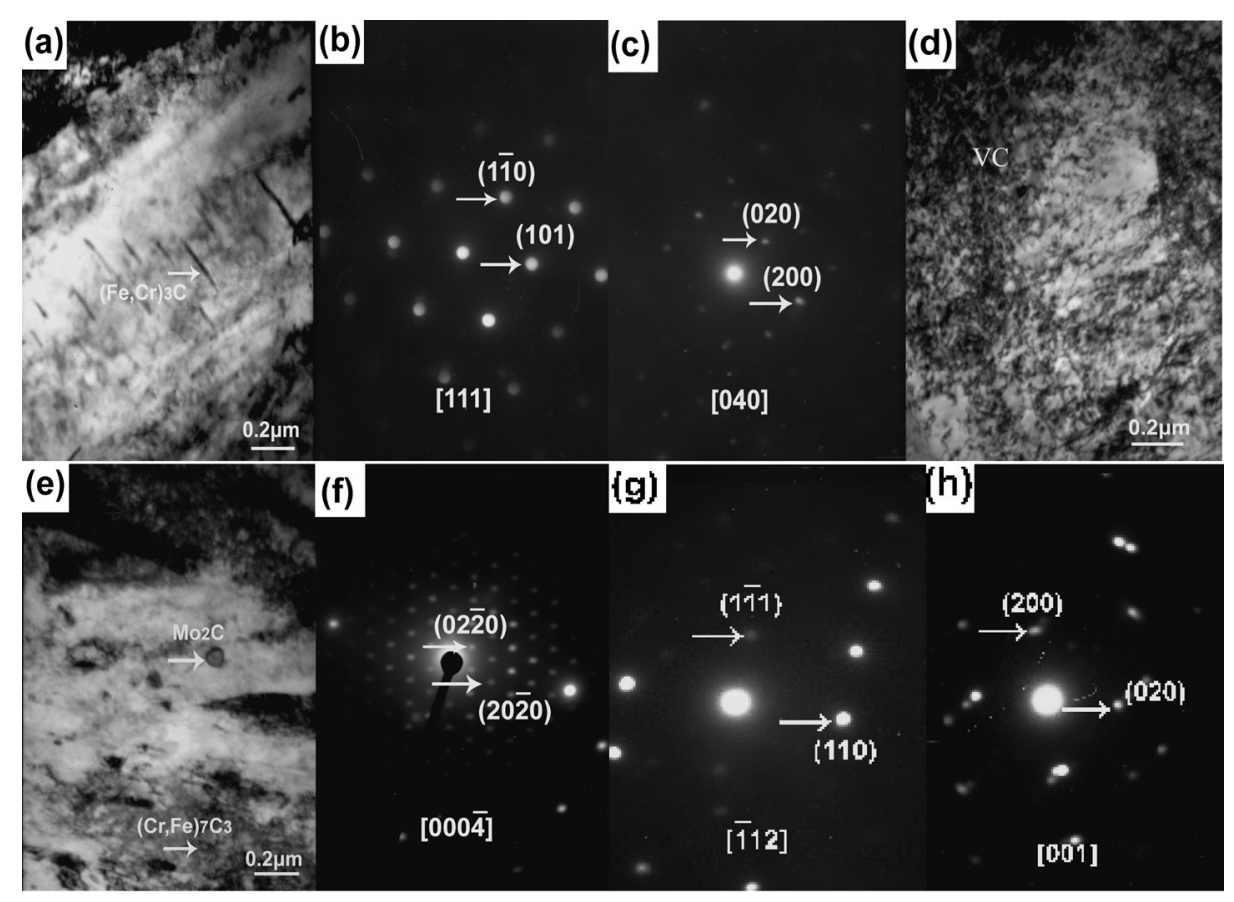

(a) $440^{\circ} \mathrm{C}, a^{\prime}+(\mathrm{Fe}, \mathrm{Cr})_{3} \mathrm{C}, \quad$ (b) SAED of a ' ${ }_{[111]}$, (c) SAED of $(\mathrm{Fe}, \mathrm{Cr})_{3} \mathrm{C}_{[040]}$,

(d) $600^{\circ} \mathrm{C}, \mathrm{VC}, \quad$ (e) $600^{\circ} \mathrm{C}, \mathrm{Mo}_{2} \mathrm{C},(\mathrm{Cr}, \mathrm{Fe})_{7} \mathrm{C}_{3}$, (f) $\mathrm{SAED}$ of $(\mathrm{Cr}, \mathrm{Fe})_{7} \mathrm{C}_{3[000} \overline{4}$ ],

(g) SAED of $\mathrm{Mo}_{2} \mathrm{C}_{[112]}^{-}$, (h) SAED of $\mathrm{VC}_{[001]}$

Fig. 1. Microstructure of the cast hot-forging die steel tempered. 
particles precipitate in $\alpha^{\prime}$ (Figs. 1(d), 1(h)). Due to presence of alloy elements and alloy carbides, tempering process is slow. Thus the microstructure tempered at temperature range from 400 to $620^{\circ} \mathrm{C}$, can be classified as tempered troosite. When tempering at $700^{\circ} \mathrm{C}, \mathrm{VC}$ slightly coarsen with re-crystallization of $\alpha^{\prime}$, which is called as tempered sorbite.

\subsection{Wear Resistance}

The elevated-temperature wear tests were carried out for the optimized steel in comparison with commercial H13 steels and $3 \mathrm{Cr} 2 \mathrm{~W} 8 \mathrm{~V}$ steel. The wear resistance and hardness of the cast steel and commercial hot-forging die steels are shown in Fig. 2. It is clear that the new-developed cast hot-forging die steel shows high wear resistance similar to H13-1 steel, whose wear rates are substantially lower than those of H13-2 steel and 3Cr2W8V steel.

It is well known that the properties of $3 \mathrm{Cr} 2 \mathrm{~W} 8 \mathrm{~V}$ steel are disappointed. Its elevated-temperature wear resistance is found to be also the worst with the highest wear rate. Similarly, the wear resistance of H13-2 steel is worse. The highpurified H13-1 steel has been known to have high properties and life. The experimental results also show that the steel possesses very high wear resistance.

Morphology of worn surfaces of the cast steel and commercial hot-forging die steels are shown in Fig. 3. Two regions are revealed on worn surfaces: undelamination region and delamination region. The undelaminated region is virtually featureless oxidized compounds, smoother than delaminated region. It is clearly found that the rough worn surfaces of H13-2 steel and 3Cr2W8V steel were revealed with deep and large delaminating area, as shown in Figs. 3(b), 3(c). In contrary, the H13-1 steel and the cast steel show mild wear with relatively smooth worn surfaces with

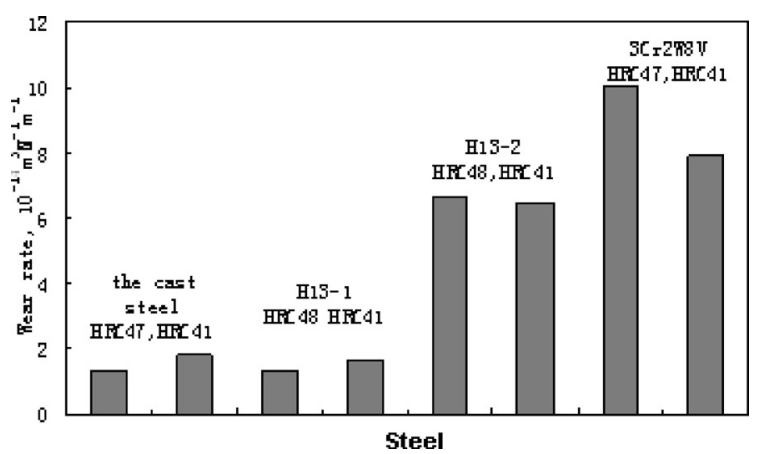

Fig. 2. Wear rates of the new-developed cast die steel, H13 steels, and $3 \mathrm{Cr} 2 \mathrm{~W} 8 \mathrm{~V}$ steel. less and shallow delaminating area, as shown in Figs. 3(a), 3(d). It is apparent that the morphology of worn surface exhibits typical oxidation wear feature. This is also confirmed from XRD on worn surfaces of pin specimens, as shown in Fig. 4. On the worn surface, oxygen is revealed in addition of dominant presence of $\mathrm{Fe}$ and main alloy elements $\mathrm{Cr}$, Mo, V. $\mathrm{Fe}_{3} \mathrm{O}_{4}$ and $\mathrm{Fe}_{2} \mathrm{O}_{3}$ are identified as the predominant oxide.

\section{Discussion}

Under atmospheric conditions, steels are thermodynamically unstable as is the case with most other metals. Dry sliding wear of steels results in formation of oxide films on the sliding surface, especially at elevated temperature. When oxide film reaches critical thickness, oxide film on the plateaus becomes unstable and break up to form wear debris because of brittleness and internal stress of oxide. Then, other load-bearing plateaus elsewhere on the surface become operative with formation of oxide film. A steady oxidational wear continue with alternating process of oxide-film formation and delamination on contacting plateau. This form of wear is called as oxidation wear or mild wear. ${ }^{21,22)}$

Generally oxidation wear behavior is closely related to

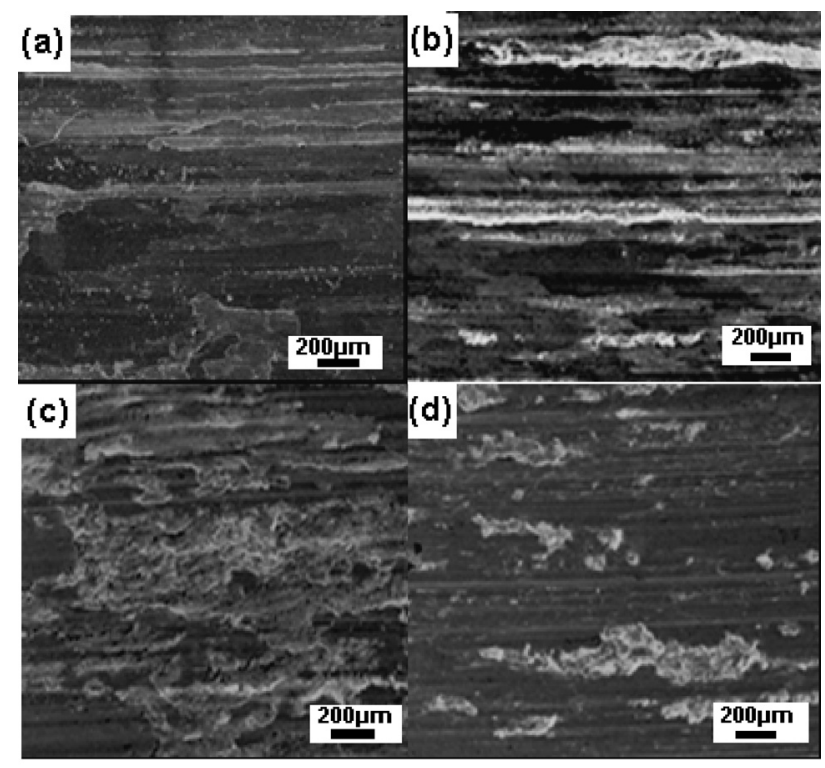

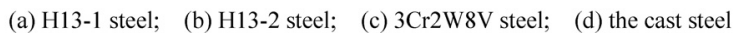

Fig. 3. Morphology of worn surfaces of the cast die steel and commercial hot-forging die steels.

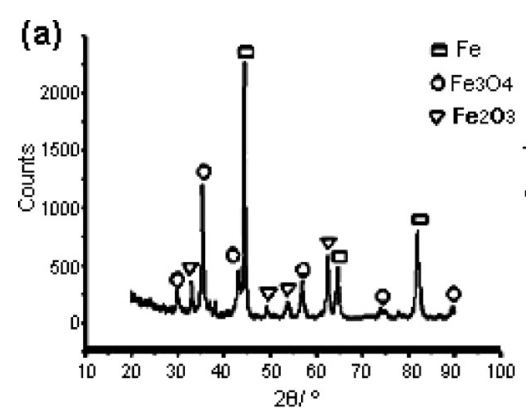

(a) the cast steel

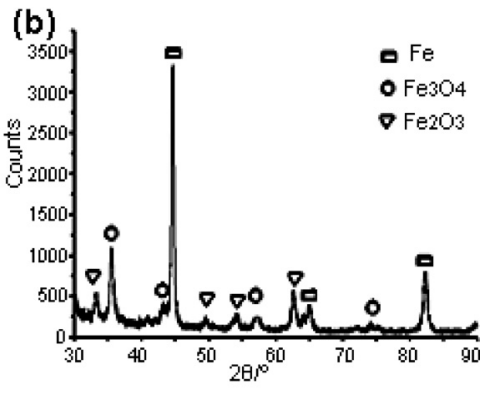

(b) H13 steel

Fig. 4. XRD of worn surfaces of pin specimens. 
oxide film. But the matrix is needed to have enough strength in wear process to restrain extra deformation of matrix for supporting oxide film. Otherwise, the severe wear occurs. ${ }^{23)}$ As a result, the thermal strength and stability is keys to binding between oxide film and matrix during elevated-temperature wear.

Table 2 lists the tensile strength data of the new-developed cast steel under different temperatures. It is clear that the cast steel possesses enough high temperature strength. Even at $600^{\circ} \mathrm{C}$, the tensile strength of the cast steel retains above $1000 \mathrm{MPa}$. So the cast steels can provide strong support for oxide film. The oxide film is not easily delaminated to grow till the critical size, thus wear rate is obviously reduced.

Table 3 compares alloying design parameters of the newdeveloped cast steel with commercial H13 steel and $3 \mathrm{Cr} 2 \mathrm{~W} 8 \mathrm{~V}$ steel. The new-developed cast steel, H13 and $3 \mathrm{Cr} 2 \mathrm{~W} 8 \mathrm{~V}$ all belong to $\mathrm{Cr}-\mathrm{Mo}(\mathrm{W})-\mathrm{V}$ system alloy steels. But they have different alloy compositions, which result in differences in microstructure and properties.

It is found in Table 3 that $\mathrm{V} / \mathrm{C}, \mathrm{C}_{\text {residual }}$ and $\mathrm{Cr} /(\mathrm{Cr}+\mathrm{Mo})$ are respectively 2.0, 0.22 and 0.87 in $\mathrm{H} 13$ steel. This gives the facts that carbide of $\mathrm{Cr}$ is more as the predominant carbide, but amount of $\mathrm{VC}$ is less. However, solution amount of $\mathrm{Cr}$ in $\alpha$-Fe is enough, because $\mathrm{Cr} / \mathrm{C}_{\text {residual }}$ is calculated to be 24.3 .

Similarly in $3 \mathrm{Cr} 2 \mathrm{~W} 8 \mathrm{~V}$ steel, $\mathrm{V} / \mathrm{C}, \mathrm{C}_{\text {residual }}$ and $\mathrm{Cr} /$ $(\mathrm{Cr}+\mathrm{Mo})$ are respectively $1.0,0.29$ and 0.53 . It is shown that more carbide of $\mathrm{W}$ is as predominant carbide with less $\mathrm{VC}$ in $3 \mathrm{Cr} 2 \mathrm{~W} 8 \mathrm{~V}$ steel. Solution amount of $\mathrm{W}$ in $\alpha$-Fe is not enough because of 13.8 of $\mathrm{W} / \mathrm{C}_{\text {residual }}$.

Through above analysis, H13 steel and $3 \mathrm{Cr} 2 \mathrm{~W} 8 \mathrm{~V}$ steel do not possess ideal thermal strength and stability during elevated-temperature wear process. And $3 \mathrm{Cr} 2 \mathrm{~W} 8 \mathrm{~V}$ steel has worse properties than H13 steel. On the contrary, in new-developed cast hot-forging die steels, a great amount

Table 2. Tensile strength data of the new-developed cast steel under different temperatures.

\begin{tabular}{ccc}
\hline & \multicolumn{2}{c}{ Tensile strength, MPa } \\
\cline { 2 - 3 } Temperature, ${ }^{\circ} \mathrm{C}$ & Yield strength & Fracture strength \\
\cline { 2 - 3 } 400 & 1185 & 1537 \\
600 & 1018 & 1456 \\
\hline
\end{tabular}

of VC as predominant carbide with less Cr- and Mo-dominant carbides and more solution of $\mathrm{Cr}$ and $\mathrm{Mo}$ in $\alpha$-Fe guarantee outstanding thermal strength and stability. Consequently the new-developed cast hot-forging die steels definitely reveals higher wear resistance than $\mathrm{H} 13$ steel and $3 \mathrm{Cr} 2 \mathrm{~W} 8 \mathrm{~V}$ steel, due to reasonable alloying design.

Except for main alloying elements, trace elements, especially S and P were well known to have evident influence on properties of steel. The high wear resistance of the H13-1 steel may be attributed to low content of S and P. Relatively, H13-2 with higher content of $\mathrm{S}$ and $\mathrm{P}$ results in low wear resistance.

$\mathrm{S}$ exists in the form of MnS. P segregates in the austenitic grain boundary, which is detrimental to grain boundary strength. After hot rolling, $\mathrm{MnS}$ and $\mathrm{P}$ may be aligned to the rolling direction. In the process of wear, they both easily result in crack initiation and propagation at $\mathrm{MnS}$ and the austenitic grain boundary along a rolling direction.

It is clear that the new-developed cast steel also has higher content of S and P, compared with commercial H13 steels. This is because the cast steel can not be effectively desulfurized and dephosphorized by no-oxidation smelting in induce furnace.

Although higher content of S and P, the cast steel reveals optimum wear resistance, similar to the H13-1 steel with low content of S and P. This can be attributed to its reasonable alloying design and no sensitivity to detrimental function of $\mathrm{S}$ and $\mathrm{P}$. The latter can be explained by lightening detrimental function through dispersed distribution of $\mathrm{MnS}$ and $\mathrm{P}$ in solidified structure. However, in as-forged steel, $\mathrm{MnS}$ and $\mathrm{P}$ are liable to segregate along rolling direction, thus result in brittleness. Generally as-forged steels are relatively sensitive to content of S and P. This can give a good explanation for apparent difference of wear resistance between H13-1 steel and H13-2 steel.

Detrimental function of $\mathrm{S}$ and $\mathrm{P}$ can be further verified through morphology of wear debris of H13 steel and the cast die steels, as demonstrated in Fig. 5. Long, thin strip of wear debris predominantly is revealed in H13-2 steel (Fig. 5(a)) and thick, lump wear debris in the cast steel (Fig. 5(b)). The segregation of MnS and $\mathrm{P}$ along rolling direction in as-forged steels causes brittleness and aggravates wear resistance.

It can be concluded that the new-developed cast hot-forging die steel has not only high wear resistance, but also low cost and energy-consuming. Additionally the cast die steel was reported to its impact toughness can reach $36.5 \mathrm{~J} / \mathrm{cm}^{2}{ }^{21)}$ As a result, the new-developed cast hot-forging die steels should satisfy requirement of properties for

Table 3. Alloying design parameters for the new-developed cast steel, H13 steels and $3 \mathrm{Cr} 2 \mathrm{~W} 8 \mathrm{~V}$ steel.

\begin{tabular}{cccccc}
\hline \multirow{2}{*}{ Steels } & \multicolumn{5}{c}{ Alloying design parameters } \\
\cline { 2 - 5 } & $\mathrm{V} / \mathrm{C}$ & $\mathrm{C}_{\text {residual }}$ & $\mathrm{Cr} /(\mathrm{Cr}+\mathrm{Mo})$ & $\mathrm{Cr} / \mathrm{C}_{\text {residual }}$ & $\mathrm{Mo} / \mathrm{C}_{\text {residual }}$ \\
\hline The cast steel & 3.12 & 0.1 & 0.72 & 36.7 & 25.7 \\
H13 & 2.0 & 0.22 & 0.87 & 24.3 & -- \\
$3 \mathrm{Cr} 2 \mathrm{~W} 8 \mathrm{~V}$ & 1.0 & 0.29 & 0.53 &.-- & 13.8 \\
\hline
\end{tabular}




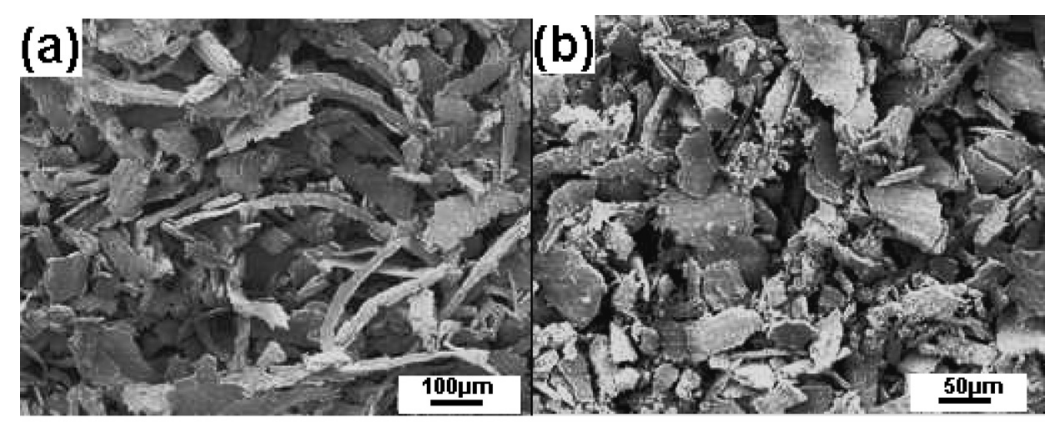

(a) H13-2 steel

(b) the cast steel

Fig. 5. Morphology of wear debris.

field application with good prospects.

\section{Conclusions}

(1) The wear resistance is the key property for the alloying design of cast hot-forging die steels. The cast hot-forging die steels with high wear resistance are developed through optimizing the parameters: $\mathrm{V} / \mathrm{C}, \mathrm{C}_{\text {residual }}$ or $\mathrm{Cr} / \mathrm{Cr}+\mathrm{Mo}$.

(2) The newly-developed cast hot-forging die steels take $\mathrm{VC}$ as predominant carbide with solid solution strengthening of $\mathrm{Cr}$ and Mo. The newly-developed cast die steel has significantly lower wear rate than H13-2 and 3Cr2W8V steels, almost the same as H13-1 steel.

(3) The high wear resistance of the newly-developed cast hot-forging die steels can be attributed to the reasonable alloying design and no sensitivity to detrimental function of $\mathrm{S}$ and $\mathrm{P}$.

(4) Under elevated-temperature air at $400^{\circ} \mathrm{C}$, the wear of the cast die steels and commercial hot-forging die steels is typical oxidation wear. $\mathrm{Fe}_{3} \mathrm{O}_{4}$ and $\mathrm{Fe}_{2} \mathrm{O}_{3}$ was found on worn surfaces. Long, thin strip of wear debris is predominantly presented in H13 steel and thick, lump wear debris in the cast steels.

\section{Acknowledgements}

The research was supported by the project of early-term key technology of Industrialization (No. 1999317) and whole set equipment from Plan Committee of China and the key-lab project (Contract No. Kjsmcx 04004) from
High Education Council of Jiangsu Province.

\section{REFERENCES}

1) P. R. Beeley and A. Blackmore: Met. Technol., 17-18 (1981), 268.

2) J. R. Fang, Q. C. Jiang and Q. F. Guan: Fatigue Fract. Eng. Mater. Compon., 25 (2002), 481.

3) P. M. Bralower: Mod. Cast., 78 (1988), 3.

4) P. R. Beeley: Br. Foundry, 76 (1983), 15.

5) P. R. Beeley: Br. Foundry, 79 (1986), 441

6) X. H. Cui, S. Q. Wang and Q. C. Jiang: Heat Treat. Met., 26 ( 2001), 17.

7) S. Q. Wang, X. H. Cui and F. Wang: Foundry, 55 (2006), 555.

8) J. J. He, J. Lan and C. Q. Zhai: Foundry, 49 (2000), 156.

9) J. R. Fang, Q. C. Jiang and Y. G. Zhao: Foundry, 51 (2002), No. 1, 7.

10) J. Lan, J. J. He and W. J. Ding: Iron Steel, 35 (2000), No. 10, 48.

11) X. H. Cui: Ph.D. Thesis of Jilin University, Changchun, (2006).

12) S. Wang and X. Cui: China Mech. Eng., 15 (2004), 746.

13) X. Z. Feng: Die Steels and Heat Treatment, Mechanic Industry Press, Beijing, (1980).

14) K. B. Muller: J. Mater. Process. Technol., 130-131 (2002), 432.

15) O. Barrau, C. Boher, R. Gras and F. Rezai-Aria: Wear, 255 (2003), 1444.

16) L. H. S. Luong and T. Heijkoop: Wear, 71 (1981), 93.

17) Q. C. Jiang, J. R. Fang and Q. F. Guan: Scr. Mater, 45 (2001), 199.

18) S. Wang, K. Cheng and X. Cui: J. Iron Steel Res. Int., 13 (2006), No. $5,53$.

19) G. L. Chen: High-temperature Alloys, Metallurgy Industry Press, Beijing, (1988).

20) R. Wilson: Metallurgy and Heat Treatment of Tool Steels, McGrawHill, New York, (1975).

21) H. So: Wear, 253 (2002), 1004.

22) G. A. Fontalvo and C. Mitterer: Wear, 258 (2005), 1491.

23) E. Marui, N. Hasegawa, H. Endo, K. Tanaka and T. Hattori: Wear, 205 (1997), 186. 